\title{
Women Reflect on Being Well in Academia: Challenges and Supports
}

Gabrielle Young, Michelle Kilborn, Christine Arnold, Saiqa Azam, Cecile Badenhorst, J. R. Godfrey, Karen Goodnough, Leah Lewis, Xuemei Li, Heather McLeod, Sylvia Moore, Sharon Penney, and Sarah Pickett (Note: The authors are members of Memorial University's Faculty of Education Writing Group)

\begin{abstract}
A narrative approach was adopted to explore the experiences of 13 women who pursued academic careers. Analysis of the personal reflective narratives uncovered themes common to the participants, also the authors of this study, which focused on striving to have work-life balance, personal and professional costs associated with being unwell, and the impact of academic work on families. Findings highlighted suggestions for being well in academia such as choose to engage in work and leisure activities that are enjoyable and maintain relationships. Suggestions for universities included: provide clear promotion and tenure processes, examine workload expectations, promote wellness, and facilitate mentorship.

Kilborn (2016) describes wellness as a balance of the mental, physical, emotional, and spiritual dimensions of the self that require present awareness and mindfulness, connecting the whole self_-body, mind, and spirit-to the collective well-being of society. It is this type of thinking-balance, interconnectedness, and wholeness - that grounds the concept of wellness and expands traditional understandings of health.
\end{abstract}

Examples of how wholeness, balance, and harmony are understood and practiced are prominent throughout wisdom traditions. For example, Hart (1999) explained the concept of wholeness through the medicine wheel (used by many Indigenous peoples such as Cree, Dakota, and Blackfoot), which is used to express relationships in sets of four, associated with the four cardinal directions: four aspects of humanness (emotional, physical, mental, spiritual); four cycles of life (birth/infancy, youth, adulthood, elder/death); four elements (fire, water, wind, earth); and four seasons (spring, summer, fall, winter).

Wholeness involves movement in/through all these aspects and is fundamental to the health of all living things. Of course, to move in this way we must recognize the need to balance our attention on the four aspects of these relationships, so one part is not emphasized to the detriment of the others. When one dimension is valued more, or when certain dimensions are not acknowledged at all, a state of "unwellness" often results.

Unfortunately, this is often the case in academic environments. Holistic understandings of how to be healthy and well do not fit with academia's dominant neoliberal discourse that reaffirms subject-object, process-product, and body-mind dichotomies (Kilborn, 2016), and does not consider the "embodied 
persons' subjective experience in the world" (Rintala, 1991, p. 274). This disconnected culture is at odds with maintaining and promoting personal wellness.

In 2009, we, the authors, started a Writing Group in our faculty, meeting weekly to discuss our practices of teaching and researching in academia. We have conducted self-studies and arts-based representations to explore issues of common concern, such as our challenges in academia and the need for professional development (Badenhorst et al., 2016; McLeod et al., 2014; Young et al., 2017). This study focused on addressing the following questions in relation to well-being in academia: a) What are the tensions of personal wellness and academia? b) How do faculty members maintain health and well-being in academe? and c) What would a wellness-oriented academe look like and feel like?

\section{Faculty Wellness}

Wellness is defined as a lifestyle centred on health, well-being, and balance among the spirit, body, and mind (Myers, Sweeney, \& Witmer, 2000), and is critical for the scholarly work and research responsibilities of faculty members within academic institutions (Hubball \& West, 2008). The strain that occurs for faculty members when wellness is not present has been linked to lower productivity, poor interactions with colleagues and students, and weak decision-making around departmental and university-wide issues (Klenke-Hamel \& Mathieu, 1990).

Within higher education faculty, wellness has become an increasing concern as a result of research reports showing that faculty stress is on the rise (Catano et al., 2007; Miller, Buckholdt, \& Shaw, 2008; Watts \& Robertson, 2011). In comparison to the general population, academics experience higher levels of stress (Catano et al., 2007), and this stress has a substantial impact on the physical and psychological health of faculty members. In research among 1,470 academics from 56 Canadian universities, 13\% of respondents recounted having "psychological strain," and 22\% reported experiencing "physical health" symptoms, with many reporting the use of medication (Catano et al., 2007, p. 38). These findings point

to a rise in faculty stress, which can potentially undermine personal and professional capabilities resulting in compromised productivity.

\section{Challenges Experienced by Academics}

Historically, despite being low-paid as compared to industry professionals, academic jobs have been "envied for their tenure, light work, flexibility, perks such as overseas trips for study and or conference purposes, and the freedom to pursue their own research interests" (Gillespie, Walsh, Winefields, Dua, \& Stough, 2001, p. 53). However, in previous decades, the nature and expectations of academic positions have changed considerably, as there has been a decrease in salaries, and an increase in workloads, pressure to attract external funding, and publish in academic journals (Gillespie et al. 2001). 


\section{Workloads}

Increases in faculty workload have been well reported in higher education research. Crespo and Bertrand (2013), in their study of workload at a large research-intensive Canadian university, determined the average weekly workload to be approximately 56.97 hours. Within these hours, the following were dedicated to each faculty function: $44.1 \%$ allocated to teaching, $35.2 \%$ to research, and $14.8 \%$ to service. The remaining time was spent on administrative tasks and communication.

The literature on faculty workload shows considerable variability in tasks performed, hours worked, and dedication to service, teaching, and research (Crespo \& Bertrand, 2013). Research on faculty workload distinctions by gender, academic rank, discipline, and country are fairly limited (Crespo \& Bertrand, 2013; Milem, Berger, \& Dey, 2000).

Teaching, research, service, and administration functions, and the constant switching between them, often results in role ambiguity and significant stress levels (Bandura \& Locke, 2003; Catano et al., 2007; Miller et al. 2008). The multifaceted professional life of academics reflects the complexity of their jobs, leading to stress that is multifold in nature. Researchers have tried to identify the sources of stress in academia. Gmelch, Wilke, and Lovrich (1986) identified common patterns for stress, noting three main sources: (i) self-expectations; (ii) excessive time constraints; and (iii) inadequate resources (p. 267). Likewise, Gillespie et al. (2001), in their review of the research conducted across the United Kingdom, United States, Australia, and New Zealand, found several key factors associated with faculty stress: (i) increased work load; (ii) time constraint; (iii) poor salary structure, (iv) fewer opportunities for promotion; (v) changing job roles; (vi) lack of recognition; and (vii) inadequate funding resources.

In addition to these stressors, more recent research identifies role ambiguity, student and technologyrelated issues, and family-work life balance as challenges (Antoniou, Polychroni, \& Vlachakis, 2006; Bandura \& Locke, 2003; Korotkov, 2008; Totten \& Schuldt, 2009). Role ambiguity is reported as one of the highest sources of stress among academics. Lack of regular feedback received by academics is particularly problematic, as feedback is necessary to enable them to better understand their role(s) and evaluate their performance (Bandura \& Locke, 2003). Lack of regular feedback provided to academics results in considerable uncertainty about their role, while positive feedback may serve as a reward leading to better performance, as well as lower levels of work-related stress. Furthermore, according to Antoniou and colleagues (2006), student interactions inside and outside the classroom, low-level engagement in classroom discussions, and problematic student attitudes, cause stress for faculty members.

Totten and Schuldt $(2008,2009)$ questioned the expectations for faculty in online teaching environments to be accessible 24/7 through the use of technology, and investigated the stress related to it. They found higher stress levels among faculty teaching online in comparison to face-to-face teaching. 


\section{Tenure and Promotion Processes}

Faculty face challenges that lead to stress as tenure and promotion processes are often vague regarding professional requirements and expectations. In order for a promotion in rank to occur, faculty must be aware of appointment, promotion, and tenure guidelines (Smith et al., 2016). Smith and colleagues (2016) determined in their research that the obscurity of these elements was an issue, and as such, they developed strategies to assist with clarity. These strategies included rubrics, checklists, and mentoring consultations, to name a few, to ensure the process was streamlined and transparent, and included a well-articulated plan for individual success. With regard to gender, research reveals that women appear to be more stressed about tenure and show greater concerns over expectations and criteria (Austin \& Rice, 1998).

In terms of new academics, research has shown they find it significantly challenging to balance academic responsibilities and their home lives (LaRocco \& Bruns, 2006; Rice, Sorcinelli, \& Austin, 2000), whereas transitioning career academics have developed "a sense of self and pay attention to [their] priorities in life to achieve a personal and professional life balance" (Crane, O'Hern, \& Lawler, 2009, p. 25). However, both sets of academics find social and professional support integral to their success in academia (Crane et al., 2009; Cruz \& Sholder, 2013; LaRocco \& Bruns, 2006).

\section{Women and Academia}

Irrespective of geographic location, cultural context, or social location, women publish less and advance in academia more slowly than men (Thanacoody, Bartram, Barker, \& Jacobs, 2006). In their self-study of 11 women's experiences in balancing family and career, Penney et al. (2015) noted while they expected gender equity in an academic career, their perceptions were wrong; gender parity did not exist in academia.

Although female faculty represent roughly one third of all full-time university faculty in North America (CAUT, 2010; Galaz-Fontes et al., 2008; West \& Curtis, 2006), they often hold lower ranks and fewer upper-level administrative positions; and in every aspect of academic career progression, they lag behind men (Krefting, 2003; Marschke, Laursen, Nielsen, \& Rankin, 2007; Ornstein, Stewart, \& Drakich, 2007; Perna, 2005).

Women in Canada are less likely than men to be hired into tenure-track positions despite receiving an increasing share of doctoral degrees (Drakich \& Stewart, 2007). Research has identified the tenure process as privileging men and suggested academic institutional structures, policies, and practices disadvantage women (Fox, 2005; Leahey, 2006; Mason, Goulden, \& Wolfinger, 2013; Perna, 2005; Valian, 2005; Williams, 2004). Women are more likely than men to be asked to demonstrate their competencies, and to work harder to prove themselves (Williams, 2004).

Wolf-Wendel and Ward (2006) suggest that even though women are increasingly earning the qualifications to enter academia, institutional barriers restrain women, particularly those with children 
and family obligations. Also, gender-based demands and expectations associated with women's roles in families, inclusive of but not limited to pregnancy and child rearing, have been shown to constrain their ability to advance in the male model of academic success and meet requirements of tenure (Mason \& Goulden, 2002). Generally, female faculty members publish less than their male equivalents, and this is particularly true for female faculty with children in Canada (Fox \& Mohapatra, 2007; Leahey, Crockett, \& Hunter, 2008; Padilla-Gonzalez, Metcalfe, Galaz-Fontes, Fisher, \& Snee, 2011; Posen, Templer, Forward, Stokes, \& Stephens, 2005).

It is widely accepted that low publication records reduce the likelihood of promotion and tenure and increase the likelihood of leaving academia (Acker \& Armenti, 2004; Hirakata \& Daniluk, 2009; Leahey et al., 2008; Penney et al., 2015; Pickett, 2017; Powell, 2013; van Anders, 2004). Furthermore, despite being equally committed to academic work and families, women report feeling guilty about dividing their time between these responsibilities, due to expectations surrounding their "second shift" of caregiving, household responsibilities, and the demands of holding an academic position (Evans, 2008; Penney et al., 2015; Pickett, 2017).

\section{Method}

Narrative inquiry is a way of understanding experience. It is a collaboration between researcher and participants, over time, in a place or series of places and involves social interaction with milieus. Simply put, narrative inquiry is stories lived and told (Clandinin \& Connelly, 2000, p. 20). As inquirers, we engaged in telling, reliving, and retelling the stories of our experiences with respect to wellness in academia.

We were interested in understanding how women have been able to remain and thrive in academia. As members of a Faculty of Education writing group at Memorial University of Newfoundland, we collectively decided to employ writing as a lens of inquiry (Richardson \& St. Pierre, 2008).

Personal narratives were used to understand the perceptions and experiences of 13 women (aged 31 to 60) who reflected on their individual journeys towards maintaining wellness in academia. We came from qualitative and quantitative research backgrounds and various fields of study, including Aboriginal education, adult education, art education, counselling psychology, Indigenous education, math education, music education, science education, second language education, social studies, special education, and wellness education. All but one of the writing group members had previous careers, having invested from two to 20 years as teachers (in varying disciplines), guidance counsellors, school psychologists, and clinical psychologists prior to transitioning into academia. At the time of writing, three of these women were on contract, five were tenure-track, and five were tenured.

\section{Data Collection Procedures}

As suggested by Lieblich, Tuval-Mashiach, and Zilbert (1998), we conceptualized our project as a "study that uses or analyzes narrative materials" (p. 2), and collected our data as "a story" in the form of personal 
wellness narratives. The first two authors asked participants in this study to write personal narratives about how they live in an academic environment and strive to maintain or promote their own mental, physical, social, and spiritual well-being. These narratives focused on: the tensions of personal wellness and academia; how faculty members maintain their health and well-being in academe; and the characteristics of a wellness-oriented academe.

\section{Data Analysis Procedures}

We employed the narrative method of thematic analysis, suggested by Riessman (1993), to address our research questions. To shed light on the emerging themes, members of the writing group were asked to share their narratives with others and to write down pertinent phrases that came to mind as the narratives were read aloud. The first author sorted the key phrases that arose from the narratives into separate thematic groups, which were presented to members of the writing group in order to further discuss how the key statements were categorized. She then reread each narrative in order to code by phrase and organize into identified themes, and then selected segments of text that were instrumental in highlighting participants' experiences surrounding wellness in academia. The selected excerpts were coded using the themes identified from the keywords when the narratives were read aloud. In reporting the results, we selected pseudonyms to represent our individual narratives.

\section{Results}

Themes emerging from the analysis include our perceptions of the nature of wellness, the personal and professional cost of being unwell, and the impact of academic life on family. Suggestions for promoting individual wellness, as well as how academe can adapt to promote faculty wellness, are described.

\section{The Nature of Wellness}

Our narratives described wellness in the academic context as being informed by a holistic perspective of wellness, and active and balanced engagement of personal, professional, and individual dimensions of the self. We felt wellness referred to a wholeness of experience, with Monica commenting, "Life can be lived fully and healthily if our mind, body, and spirit are intertwined with every experience. An absence or loss of any of these can easily create an imbalance." Other individuals related wellness to a wellbalanced life. June felt, "Wellness means the balance of mind and body, work and life. Wellness means we have time to engage in recreational activities and are able to take care of our family members and property." We agreed wellness needed to be viewed from a holistic perspective, and discussed the need to consider an Indigenous worldview. Susan shared that, "The circle has four parts that represent the four aspects of being human: mind, body, heart, and spirit. When these four parts of my life are in a state of equilibrium, I have wellness in my life."

We also agreed wellness means having a balanced life, which is perceived as not working all the time. Robin described wellness as, "being physically well but also having a balanced life... being fit and healthy 
but also having different interests and pursuits outside of work... [and] not having that burden, that weight of responsibility every moment of every day."

\section{Personal and Professional Cost of Being Unwell}

The personal and professional costs of being "unwell" were evidenced through the sharing of critical events of personal and family health crises, and the discussion of competitive environments which led to career and personal sacrifices and feelings of institutional oppression. We felt that a career in academia was at odds with maintaining wellness, with Abbey lamenting,

Unlike the service industry or some forms of medical professions, where you cannot serve tables or care for patients when you are at home during off hours, the flexibility of an academic profession impacted my ability to turn down my innate sense of guilt and desire to work.

Similarly, June stated, "I can only talk about the ideal situation, as I have not been successful in healthy living as an academic... PhD refers to 'permanent health damage'." In elaborating on the various forms of ill health she experienced while employed as an academic, June said, "I suffered severe pain and unknown skin irritations and allergy symptoms. The doctor said everything was caused by stress, but I was not convinced until much later."

In the same vein, Roxanne noted, "In the past year I have been referred to three specialists - an allergist, ears nose and throat, and dermatologist." She also noted the negative impact on her well-being: "Prior to moving into an academic environment I exercised just about daily. It would be rare that as a family we didn't bike, walk, or swim regularly... I still have a membership to the gym, but I actually have not used it in over a year." She felt, "I achieved tenure... at the expense of my own wellness and physical health. I packed on about 45 pounds of weight... I am now wondering if this job is worth this risk?"

Patricia's comments epitomized the sentiments of the group: "Multitasking, over-loaded schedules, moreis-better mentality, productivity-at-any-cost perspectives... this leads to disconnectedness, distractedness, and escape from experience, which is a key source of increasing physical and mental illness in society."

\section{Impact of Academic Work on Families}

We felt an academic career affected our lives, as well as the lives of our family members. Kingston asked herself:

What are my children, now four and five, learning when I opt to stay home and work rather than go to their swimming lessons, and when there is tension in the air with my partner because "work-related" and academia-related anxiety has crept into our home?

Kingston continued to reflect on how an academic career affected her children:

What decisions are my children coming to about their own worthiness, and what am I saying to my partner and co-parent when I postpone our time together to send one last email, to take one more phone call from a student? 
Abbey questioned how her actions influenced relationships: "In acquiring my life goals and pursuits, I sometimes wonder what I have lost along the way and how it has impacted my relationships." Kingston's comments encapsulated the sentiments and concerns surrounding maintaining wellness in academia: "Academia and wellness, in my experience, are inherently at odds. Wellness, scarcity and fear are incompatible. Academia cultivates scarcity and fear. There is never enough funding, enough time, enough resources."

\section{Being Well in Academia}

Our narratives and discussions yielded many suggestions for being well in academia. Recommendations for faculty included: recognize that your work is important, engage in work and leisure activities you enjoy, maintain relationships, refrain from comparison, and take time to reflect and enjoy nature and wildlife. Recommendations for universities included: provide clear promotion and tenure processes, examine workload expectations, and provide access to mentorship programs.

\section{Recommendations for faculty.}

Recognize your work is important. We recognized that in order to maintain wellness in academia, we must value the work we do. Susan said, "The primary way I maintain wellness in academe is by believing what I do matters. Teaching always matters." Group members agreed when Susan noted, "We have to be responsible to ourselves and our own health first because, without this, we cannot do the work we are called to do."

Engage in work and leisure activities you enjoy. In order to maintain wellness, participants felt individuals must continue to engage in work and leisure activities they enjoy. The writing group agreed with Monica who said, "In an academic environment, with all the pressure of deadlines, it is easy to give up on other activities that are important for us to have a work-life balance, such as Zumba, TV, walking, and talking." Robin said, "If I enjoy what I am doing, I feel well and balanced. But often I give up on what I enjoy in order to meet other people's demands and that's when I don't feel balanced." Individuals commented on the importance of engaging in a variety of enjoyable activities, with Robin saying, "There are a number of things that have allowed me to keep a level of sanity throughout my career, such as running, arts and crafts, and massage."

Maintain relationships. Abbey wanted to, "remind junior faculty, like myself, to think about values and goals, and allow themselves to preserve time for what they value and set boundaries that support building and maintaining relationships." In discussing the importance of maintaining relationships, Abbey felt,

Having a strong connection with your community, friends and family provides you with a sense of balance, and the opportunity to participate in other roles, such as that of a volunteer, friend, sibling, caregiver, and parent, which may provide a sense of resiliency when faced with academic setbacks.

Alice's words also aligned with these sentiments, 
One has to be engaged and motivated to be successful as an academic, one has to feel she is part of a supportive community, and one has to feel that she is contributing in a positive way to the overall functioning of the community.

Moreover, she noted, "Moving beyond the scope of your faculty or university can also be positive in terms of maintaining well-being. Networking with other individuals outside your university who work on topics and projects that are similar to yours can be beneficial."

Stay out of comparison and avoid competition. Our narratives addressed the negative implications of engaging in social comparison, with Abbey saying,

Although I never aspired to be a top-producing academic, I always found myself using them as my social barometer which resulted in me feeling lesser than... The problem is, in modeling my C.V., I only compared myself to those with superior academic performance.

Monica reflected on this culture of competition:

... the way academic life deems us as being successful is completely at odds with my philosophy of wholeness, healing, and contentment. For example, as a new faculty member, I have already started feeling the pressure of the tenure process. There is a sense of competition, which as educators we all know is unhealthy.

Seek nature and water to calm you and take time to reflect. In order to maintain wellness as an academic, our narratives suggested that we should go back to the trees and seek water to calm us. Patricia believed that, "The trees encourage the stillness that is needed to recover the mind-body-spirit connection... [This] is critical to restoring balance and unity in ourselves and the world." Narratives also addressed the benefits of taking time to reflect, with Alice commenting,

Another important strategy is to be self-reflective. This can take the form of keeping a personal/professional journal about how things unfold, why they unfold the way they do, and how things can be changed if you wish to change them.

Mary discussed the importance of considering one's work style, saying, "I've come to understand that I'm most productive in the morning, least at night... I sometimes bring work home as a reassuring act, but truly know I'Il not touch it before the next morning." Similarly, Patricia said, "Contemplation and meditative sensibility are a key tenet to a wellness way of being and a way to recover the unity of body, mind, spirit, and heart."

\section{Recommendations for universities.}

Provide clear promotion and tenure processes. While narratives highlighted a desire to maintain worklife balance, June noted,

I was pressured to apply for research funding - I exhausted all sources that I knew of from the faculty, to university, to SSHRC. I was not pressured by anyone in particular but by the academic atmosphere I felt around me. Everyone had a PhD and everyone was competitive. 
Narratives addressed the importance of having clear promotion and tenure processes so that individuals do not set unrealistic expectations for themselves. Robin said, "I don't have a boss who tells me what I should be doing." However, she elaborated, "I think we get our training in ignoring our own needs as doctoral students. We learn then how to drop our boundaries and be available for work all of the time." As a whole, we felt guidelines surrounding required roles and responsibilities would allow us to set boundaries. Robin said, "I take on and want to do too much, I get things done so people ask me to do more and I find it very difficult to say 'No' to people I like, especially graduate students."

Examine workload expectations. Narratives highlighted how difficult it is for academics to decline academic service. Robin said, "I was pressured into conducting a review of my program (work I do not enjoy). I tried hard to postpone the review (and all the course development afterwards) but was really pressured to do it." Narratives highlighted the importance of the academy respecting boundaries, as suggested by Roxanne,

I had to work extremely hard at learning to say "no" to requests for service... Recently my Dean asked me to sit on a committee I did not want to sit on... I said no four times, and then finally, because the Dean would not give up, I relented and agreed to serve.

Narratives addressed the stressors of having to document our work, and the realization that all of the work is not taken into account. Robin stated, "We apply for grants, send in proposals for book chapters, send queries for books, talk about books, papers with others, etc. Some of them are successful and others aren't." With this in mind, we felt promotion and tenure committees should consider all work, including successful and unsuccessful grant applications and publications. We also suggested institutions should promote wellness, with Theresa recommending that, "the [university] sponsor quality experiential wellness programs with convenient times and very knowledgeable leaders who offer individual counseling."

Provide access to mentorship programs. Narratives addressed the benefits of participating in a writing group, with Theresa noting, "The writing group in our faculty has been particularly helpful for me in regard to overcoming potential social isolation as an academic. Over several years, we've shared professional strategies and worked on collaborative research and publishing projects." Narratives emphasized the importance of mentorship, with Abbey saying, "I can see the value of having a formal mentorship program to help new faculty become acculturated to the norms and expectations of academe." While universities could facilitate this process, Alice stated, in regard to maintaining health and well-being in academia, "Another important strategy for new academics is to find a mentor who can be a sounding board for concerns, issues, successes, and challenges."

\section{Discussion}

Wellness awareness is informed by the individual as well as the context. At an individual level, everincreasing pressures and demands of academic life present many tensions for faculty members' ability to live and be well, including ongoing struggles to navigate expectations of publication and teaching, 
while maintaining a healthy personal life. Work-life balance is often not achieved, as many academics experience a pull between personal and professional identities and demands. This leads to compromised productivity, little or ineffective student interaction, less involvement in departmental decision making, and overall decreased life satisfaction as it relates to work and workplace (Hill, 2004). Our results don't dismiss the importance of our work, but push forward a priority that wellness is connected to the integrity of our professional identities. Collegiality and richness of relationship can dilute tendencies to compare and compete.

Universities can be instrumental in promoting wellness in academe. Pre-tenured faculty, in particular, face the unique challenge that demands their availability for any and all opportunities that will influence their career trajectory (Hill, 2004). Furthermore, efforts made to avert overload by limiting academic or administrative responsibilities may negatively inform perceptions of commitment to scholarship. Within academic life, work-related stress is often linked to struggling to meet unrealistic expectations, including fast and efficient publication. This is frequently coupled with an immediate adjustment to the academic culture that involves multiple, simultaneous engaged roles. In addition to clear and supportive communication of the tenure process, university faculties can promote wellness as a systemic imperative. For example, universities can support pre-tenured faculty with mentorship initiatives that treat wellness as a key component of academic life.

When wellness becomes a focus in university contexts, faculty members feel better supported and are more likely to meet the demands of scholarship, research, and teaching. Faculties that are collegial and collaborative continue to produce innovative and engaged work, while also maintaining motivation among faculty. Co-created research offers opportunity for diverse thought, interdependent process, as well as increases in solidarity among like-minded peers (Christianakis, 2010). Collaborative learning and research communities encourage, what Hubball and West (2008) refer to as, interdependent and mutually supportive work environments that efficiently come together to meet institutional missions. As Lindholm and Szelényi (2008) concluded, it is critical that we "strive to develop habits of conducting our work and our lives in ways that promote both our own and others' well-being" (p. 36).

In terms of gender, Bonawitz and Andel (2009) suggested women in academia should not be silent about the stresses placed on them in the context of a society that continues to pressure women to be caregivers, as these gendered expectations for caregiving interfere with academic productivity, and contribute to increased stressors, fears, and conflict associated with successful promotion and tenure (Bonawitz \& Andel, 2009; Penney et al., 2015; Pickett, 2017; Schoening, 2009; Wolf-Wendel \& Ward, 2006). Given the psychological benefits of employment, it behooves universities to consider facilitating support groups to provide women academics with opportunities to develop supportive communities that foster collaboration in navigating the conflicting roles of parent, caregiver, and academic (Barnett \& Baruch, 1985; Penney et al., 2015). 


\section{Conclusions}

We have shown that there are broader structural mechanisms that sustain unwellness and that, often, these mechanisms are invisible. The results are a normalizing of being unwell and a propensity for individualized solutions. We have found forming a writing group has allowed us to move beyond this normalized position. After all, we cannot all be the problem. The research literature on writing groups underscores the value of these types of groups in supporting new academics (Galligan et al., 2003; Lee \& Boud, 2003; Morss \& Murray, 2001).

Writing groups facilitate supportive colleagues and allow mentoring relationships to develop naturally. They help new faculty develop confidence and a sense of identity (Gillespie et al., 2005; Pasternak, Longwell-Grice, Shea, \& Hanson, 2009). Research also indicates writing groups are especially beneficial for women academics (Grant \& Knowles, 2010). We have found our writing group allowed us to see unwellness as something we experienced as a group, rather than an individual flaw. Moreover, it created the environment for multifaceted mentoring that included emotional support when appropriate. As a group, we have worked hard to create a safe environment for members (Badenhorst et al., 2013). We do not claim that writing groups are automatically centres of wellness; however, regular meetings and interactions remind us to resist the normalizing of unwellness and provide a collaborative space to support each other to live and be well in academia.

\section{References}

Acker, S., \& Armenti, C. (2004). Sleepless in academia. Gender and Education, 16(1), 3-23. doi:10.1080/0954025032000170309

Antoniou, A. S., Polychroni, F., \& Vlachakis, A.-N. (2006). Gender and age differences in occupational stress and professional burnout between primary and high school teachers in Greece. Journal of Managerial Psychology, 21(1), 682-690. http://dx.doi.org/10.1108/02683940610690213

Austin, A. E., \& Rice, R. E. (1998). Making tenure viable. Listening to early career faculty. American Behavioral Scientist, 41(5), 736-754.

Badenhorst, C. M., Joy, R., Penney, S., Pickett, S., Hesson, J., Young, G., et al. (2016). Becoming an academic: Reflective writing and professional development. In G. Ortoleva, M. Bétrancourt, \& S. Billet (Eds.), Writing for professional development (pp. 340-359). Leiden, The Netherlands: Brill Publishers. doi:10.1163/9789004264830_138

Badenhorst, C. M., Penney, S., Pickett, S., Joy, R., Hesson, J., Young, G., et al. (2013). Writing relationships: Collaboration in a faculty writing group. All Ireland Society for Higher Education, 5(1), 1001-10026.

Bandura, A., \& Locke, E. A. (2003). Negative self-efficacy and goal effect revisited. Journal of Applied Psychology, 88(1), 87-99. doi:10.1037/0021-9010.88.1.87

Barnett, R. C., \& Baruch, G. K. (1985). Women's involvement in multiple roles and psychological distress. Journal of Personality and Social Psychology, 49, 135-145. 
Bonawitz. M., \& Andel, N. (2009). The glass ceiling is made of concrete: The barriers to promotion and tenure of women in American Academia. ERIC EJ870462. Retrieved from http://files.eric.ed.gov/fulltext/Ej870462.pdf

Canadian Association of University Teachers (CAUT). (2010). CAUT Almanac of postsecondary education 2010-2011. Ottawa: Canadian Association of University Teachers.

Catano, V., Francis L., Haines T., Kirpalani, H., Shannon H., Stringer, B., et al. (2007). A survey of occupational stress among Canadian university academic staff. Ottawa: Canadian Association of University Teachers.

Christianakis, M. (2010). Collaborative research in teacher education. Issues in Teacher Education, 19(2), 109-125.

Clandinin, D. J., \& Connelly, F. M. (2000). Narrative inquiry: Experience and story in qualitative research. San Francisco: Jossey-Bass.

Crane, B., O'Hern, B., \& Lawler, P. (2009). Second career professionals: Transitioning to a faculty role. Journal of Faculty Development, 23(1), 24-29.

Crespo, M., \& Bertrand, D. (2013). Faculty workload in a research intensive university: A case study. CIRANO, Quebec: Canada.

Cruz, L., \& Sholder, J. (2013). From hills to halls: A modern parable of transitioning to academia. Journal of the Scholarship of Teaching and Learning, 13(4), 1-10.

Drakich, J., \& Stewart, P. (2007). After 40 years of feminism: How are university women doing? Academic Matters: The Journal of Higher Education, (February) 6-9.

Evans, E. (2008). Fitting in. In E. Evans \& C. Grant (Eds.), Mama PhD: Women write about motherhood and academic life (pp. 49-54). New Brunswick, NJ: Rutgers University Press.

Fox, M. F. (2005). Gender, family characteristics, and publication productivity among scientists. Social Studies of Science, 35(1), 131-150. doi:10.1177/0306312705046630

Fox, M. F., \& Mohapatra, S. (2007). Social-organizational characteristics of work and publication productivity among academic scientists in doctoral granting departments. Journal of Higher Education, 78(5), 542-570.

Galaz-Fontes, J., Padilla-González, L., Gil-Antón, M., Sevilla-García, J. J., Arcos-Vega, J. ～L., ～\& Martínez-Stack, J. (2008). Mexican academics at the turn of the twenty-first century: Who are they, and how do they perceive their work, institutions, and public policies. RHIE International Seminar Reports, $12,345-361$.

Galligan, L., Cretchley, P., George, L., Martin, K., McDonald, J., \& Rankin, J. (2003). Evolution and emerging trends of university writing groups. Queensland Journal of Educational Research, 19(1), 28-41. Retrieved from http://eprints.usq.edu.au/704

Gillespie, D., Dolsak, N., Kochis, B., Krabill, R., Lerum, K., Peterson, A., et al. (2005). Research circles: Supporting the scholarship of junior faculty. Innovative Higher Education, 30(3), 149162. doi:10.1007/s10755-005-6300-9 
Gillespie, N. A., Walsh, M., Winefields, A. H., Dua, J., \& Stough C. (2001). Occupational stress in universities: Staff perceptions of the causes, consequences, and moderators of stress, Work \& Stress, 15(1), 53-72. doi:10.1080/02678370110062449

Gmelch, W. H., Wilke, P. K., \& Lovrich, N. P. (1986) Dimensions of stress among university faculty: Factor-analytic results from a national study. Research in Higher Education, 24(3), 266-286.

Grant, B., \& Knowles, S. (2010). Flights of imagination: Academic women be(com)ing writers. International Journal for Academic Development, 5(1), 6-19. doi:10.1080/136014400410060

Hart, M. A. (1999). Seeking mino-pimatasiwin: An Aboriginal approach to social work practice. Native Social Work Journal, 2(1), 91-112.

Hill, N. (2004). The challenges experienced by pretenured faculty members in counselor education: A wellness perspective. Counselor Education and Supervision, 44(2), 135-146.

Hirakata, P. E., \& Daniluk, J. C. (2009). Swimming upstream: The experience of academic mothers of young children. Canadian Journal of Counselling, 43(4), 283-294.

Hubball, H., \& West, D. (2008). Faculty wellness strategies: Critical foundations for the scholarship of teaching and learning. Transformative Dialogues, Teaching \& Learning Journal, 2(1), 1-11, Article 2.

Kilborn, M. (2016). A curriculum of wellness: Reconceptualizing physical education.

New York: Peter Lang.

Klenke-Hamel, K. E., \& Mathieu, J. E. (1990). Role strains, tension, and job satisfaction influences on employees' propensity to leave: A multi-sample replication and extension. Human Relations, 43, 791807.

Korotkov, D. (2008). Does personality moderate the relationship between stress and health behavior? Expanding the nomological network of the five-factor model. Journal of Research in Personality, 42(6), 1418-1426. http://dx.doi.org/10.1016/j.jrp.2008.06.003

Krefting, L. (2003). Intertwined discourses of merit and gender: Evidence from academic employment in the USA. Gender Work and Organization, 10(2), 260-278.

LaRocco, D. J., \& Bruns, D. A. (2006). Practitioner to professor: An examination of second career academics' entry into academia. Education, 126(4), 662-639.

Leahey, E. (2006). Gender differences in productivity: Research specialization as a missing link. Gender \& Society, 20(6), 754-780. doi:10.1177/0891243206293030

Leahey, E., Crockett, J. L., \& Hunter, L. A. (2008). Gendered academic careers: Specializing for success? Social Forces, 86(3), 1274-1309.

Lee, A., \& Boud, D. (2003). Writing groups, change and academic identity: Research development as local practice. Studies in Higher Education, 28(2), 187-200. doi:10.1080/0307507032000058109

Lieblich, A., Tuval-Mashiach, R., \& Zilber, T. (1998). Narrative research: Reading, analysis, and interpretation. Thousand Oaks, CA: Sage. 
Lindholm, J., \& Szelényi, K. (2008). Faculty time stress: Correlates within and across academic disciplines. Journal of Human Behaviour in the Social Environment, 17(1/2), 19-40. doi:10.1080/10911350802165437

Marschke, R., Laursen, S., Nielsen, J. M., \& Rankin, P. (2007). Demographic inertia: An immodest proposal to achieve equitable gender representation among faculty in higher education. The Journal of Higher Education, 78(1), 1-26.

Mason, M. A., \& Goulden, M. (2002). Do babies matter? The effect of family formation on the lifelong careers of academic men and women. Academe, 88(6), 21-27.

Mason, M. A., Goulden, M., \& Wolfinger, N. H. (2013). Families in focus: Do babies matter? Gender and family in the ivory tower. New Brunswick, NJ: Rutgers University Press.

Mcleod, H., Penney, S., Joy, R., Badenhorst, C. M., Vaandering, D., Pickett, S., et al. (2015). Collaboration and collaborative knowledge construction through arts-based representation: Explorations of a faculty writing group. In D. Conrad \& A. Sinner (Eds.), Creating together: Participatory, communitybased and collaborative arts practices and scholarship across Canada (pp. 209-226). Waterloo, ON: Wilfrid Laurier University Press.

Milem, J. F., Berger, J. B., \& Dey. E. L. (2000). Faculty time allocation: A study of changes over twenty years. Journal of Higher Education, 71, 454-475.

Miller, G., Buckholdt, D., \& Shaw, B. (Eds.). (2008) "Faculty Time Stress" Special issue of Journal of Human Behaviour in the Social Environment, 17(1/2), doi:10.1080/10911350802165403

Morss, K., \& Murray, R. (2001). Researching academic writing within a structured programme: Insights and outcomes. Studies in Higher Education, 26(1), 35-52. doi:10.1080/03075070125020

Myers, J. E., Sweeney, T. J., \& Witmer, J. M. (2000). The Wheel of Wellness counseling for wellness: A holistic model for treatment planning. Journal of Counseling \& Development, 78, 251-266.

Ornstein, M., Stewart, P., \& Drakich, J. (2007). Promotion at Canadian universities: The intersection of gender, discipline, and institution. Canadian Journal of Higher Education, 37(3), 125 .

Padilla-Gonzalez, L., Metcalfe, A. S., Galaz-Fontex, J. F., Fisher, D., \& Snee, I. (2011). Gender gaps in North American research productivity: Examining faculty publication rates in Mexico, Canada, and the U.S. Compare, 41(5), 649-668. doi:10.1080/03057925.2011.564799

Pasternak, D. L., Longwell-Grice, H., Shea, K. A., \& Hanson, K. L. (2009). Alien environments or supportive writing communities? Pursuing writing groups in academe. Arts \& Humanities in Higher Education, 8(3), 355-367. doi:10.1177/1474022209339958

Penney, S., Young, G., Badenhorst, C., Goodnough, K., Hesson, J., Joy, R., et al. (2015). Balancing family and career on the academic tightrope. Canadian Journal of Higher Education, 457(4), 457-479.

Perna, L. W. (2005). Sex differences in faculty tenure and promotion: The contribution of family ties. Research in Higher Education, 46(3), 277-307.

Pickett, S. (2017, March). Legacy and vulnerability: Queer parenting in the academy. In E. Berger \& C. DeRoche (Eds.). The parent track: Timing balance and choice in academia. Wilfrid Laurier University Press: Waterloo. 
Posen, M., Templer, D. I., Forward, V., Stokes, S., \& Stephens, J. (2005). Publication rates of male and female academic clinical psychologists in California. Psychological Reports, 97(3), 898-902.

Powell, K. (2013). Breaking the glass ceiling while being a mother: Parenting, teaching, research, and administration. In M. Castaneda \& K. Isgro (Eds.), Mothers in academia (pp. 46-56). New York: Columbia University Press.

Rice, R. E., Sorcinelli, M. D., \& Austin, A. E. (2000). Heeding new voices: Academic careers for a new generation (Inquiry \#7. Working Paper Series). New pathways: Faculty careers and employment for the 21st century. ERIC Document No. ED451740.

Richardson, L., \& St. Pierre, E. A. (2008). Writing: A method of inquiry. In N. K. Denzin and Y. S. Lincoln (Eds.), Collecting and interpreting qualitative materials (3rd edition) (pp. 959-978). Thousand Oaks, CA: Sage Publications.

Riessman, C. K. (1993) Narrative analysis. Qualitative Research Methods Series, No. 30. Newbury Park, CA: Sage.

Rintala, J. (1991). The mind-body revisited. Quest, 43, 260-279.

Schoening, A. M. (2009). Women and tenure: Closing the gap. Journal of Women in Educational Leadership, 7(2), 77-92. ERIC Document No. EJ848872

Smith, S., Hollerbach, A., Donato, A., Edlund, B., Atz, T., \& Kelechi, T. (2016). Streamlining appointment, promotion, and tenure procedures to promote early career faculty success. Journal of Professional Nursing, 32(5), 334-341.

Thanacoody, P. R., Bartram, T., Barker, M., \& Jacobs, K. (2006). Career progression among female academics: A comparative study of Australia and Mauritius. Women in Management Review, 21(7), 536553. doi:10.1108/09649420610692499

Totten, W. J., \& Schuldt, B. A. (2008). Technological factors and business faculty stress. Proceedings of the Academy of Information and Management Sciences, 12(1), 13-19.

Totten, W. J., \& Schuldt, B. A. (2009). Stress on marketing faculty. Proceedings of the Academy of Marketing Studies, 14(1), 55-59.

Valian, V. (2005). Beyond gender schemas: Improving the advancement of women in academia. Hypatia, 20(3), 198-213. doi:10.1353/hyp.2005.0111

van Anders, S. M. (2004). Why the academic pipeline leaks: Fewer men than women perceive barriers to becoming professors. Sex Roles, 51(9-10), 511-521. doi:10.1007/s11199-004-5461-9

Watts, J., \& Robertson, N. (2011). Burnout in university teaching staff: A systematic literature review. Educational Research, 53(1), 33-50. doi:10.1080/00131881.2011.552235

West, M. S., \& Curtis, J, W. (2006). AAUP faculty gender equity indicators 2006. Washington, DC: American Association of University Professors.

Williams, J. C. (2004). Hitting the maternal wall. Academe, 90(6), 16-20. doi:10.2307/40252700

Wolf-Wendel, L. E., \& Ward, K. (2006). Academic life and motherhood: Variations by institutional type. Higher Education, 52(3), 487-521. doi:10.1007/s10734-0050364-4. 
Young, G., Penney, S., Anderson, J., Badenhorst, C., Dawe, N., Goodnough, K., et al. (2017). Women reflect on their journeys toward becoming academics: Challenges and supports. In T. Handford \& $\mathrm{T}$. Sibbald (Eds.), The academic gateway: Understanding the journey to tenure. University of Ottawa Press.

\section{About Memorial University's Faculty of Education Writing Group}

In 2009, a group of members from a Faculty of Education began meeting to share their writing and discuss the writing process. We meet regularly and each member takes a turn hosting the meeting. There are no strict deadlines and action items for the meetings; instead, each member takes a turn checking in with the group and asking for feedback or advice on their writing. It is a relaxed and open setting where networking and socializing are as welcome as producing results. The group deliberately set forth to create an environment of non-criticism—we can give feedback but not criticism and we agree to promote support, rather than competition. Through this process, the writing group has served to foster a sense of belonging. 